\title{
International Society For Knowledge Organization General Assembly Agenda
}

I am very pleased to invite you to the $13^{\text {th }}$ ISKO General Assembly which will take place the 8th August 2012 at 17:00 at the University of Mysore, India, at the $12^{\text {th }}$ ISKO Conference. All ISKO members are encouraged to attend both the Conference and the General Assembly. (The Executive Committee will meet a day before.)

The proposed Agenda is as follows:

1. Opening

2. Election of General Assembly Chair and the Secretary

3. Approval of \& Additions to the Agenda

4. Minutes of $12^{\text {th }}$ General Assembly, February 25, 2010, Rome, Italy

5. President's Report

6. Secretary / Treasurer's Report; Auditor's Report; Approval

7. Election of Three Executive Board Members 2012-2016

8. Election of Auditors 2012-2014
9. Reports from Chapters

10. Membership Fees

11. Reduced Status, Institutional Status, Chapter Status, Exchange Status, Student Chapter

12. Awards

13. KO Journal Report

14. Other ISKO Publications

15. Report on the ISKO Web

16. Report on the Bibliography

17. Report on Cooperation

18. ISKO International Conference 2014 in Krakow, Poland

19. Information on ISKO International Conferences 2016 and Later

20. Other Business and Projects

I look forward very much to seeing as many ISKO members as possible at the 12th International Conference and at this 13th General Assembly in India.

H. Peter Ohly, ISKO President 